Anders Szczepanski är fil. lic. och doktorand vid Linköpings universitet och knuten till det ämnesdidaktiska forskningsområdet vid Institutionen för beteendevetenskap och lärande (IBL). Han förestår Nationellt Centrum för Utomhuspedagogik (NCU) och arbetar med att utveckla det utomhuspedagogiska undervisningsområdet, där det svenska och internationella mastersprogrammet i utomhuspedagogik ingår. Anders har också en magisterutbildning i biologi, kemi, geografi och geovetenskap. Hans didaktiska forskningsintresse är riktat mot den fysiska miljöns betydelse för lärande och undervisning i ett utomhuspedagogiskt sammanhang.

\title{
Platsens betydelse för lärande och undervisning - ett utomhuspedagogiskt perspektiv
}

\begin{abstract}
The study describes how 19 teachers linked to preschool and comprehensive school experience the importance of place for learning and teaching in an outdoor educational context. The methodological approach is phenomenographic. The semi-structured interviews are based on pictorial material intended to illustrate different physical learning environments. Nine categories and four place-related perspectives can be distinguished. The result shows that there is sometimes a didactic uncertainty around places for teaching and learning outside the classroom walls. The availability of different places in the outdoors, a woodland environment and natural materials is seen as meaningful complements in teaching. Town settings, parks and industrial landscapes are to a lesser degree perceived as learning environments. The study shows the experience of teachers using other contexts for learning and teaching than the classroom. Outdoor education is experienced as a place-related toolkit with opportunities to integrate different subjects and anchor teaching in the real world.
\end{abstract}

\section{INLEDNING}

De senaste åren har intresset för utomhuspedagogik stadigt ökat bland lärare verksamma i förskoleklass och grundskolans tidigare år (Szczepanski, 2011). Syftet med denna artikel är att beskriva och analysera lärares uppfattningar av lärmiljöer ur ett utomhuspedagogiskt perspektiv. Inledningsvis belyses olika plats- och lärandeperspektiv från en teoretisk bakgrund. Därefter presenteras intervjuundersökningen av lärares erfarenheter av undervisning i andra lärmiljöer än klassrum utifrån en fenomenografisk analys. Forskningsfrågan är: vilka uppfattningar har lärare av platsens betydelse för lärande och undervisning utomhus?

\section{Platsens innebörder - teoretiska och normativa bestämningar}

Våra relationer till platser kommer till uttryck på många olika sätt. I ett undervisnings- och lärandesammanhang är platsen "i klassrummet" ofta tagen för given och därmed också den didaktiska var-frågan. Denna fråga riktar sitt fokus mot den fysiska utomhusmiljön och vilka platser som lärare uppfattar som lämpliga för lärande och undervisning. Utomhuspedagogiken möjliggör här ett platsbaserat lärande och undervisning som tydlig- och synliggör lärandeobjektens situerade natur i en växelverkan mellan textbaserad (intellektuella redskap, diskursiv praktik) och icke textbaserad praktik (fysiska redskap). Det vill säga en hantering av undervisningens intellektuella och fysiska 
aspekter. Ett sådant platsrelaterat möte utanför skolans väggar lyfter den didaktiska var-frågan och därmed platsens betydelse för undervisnings- och lärandesammanhang och skapar möjligheter till autentiska möten och en växelverkan mellan teori och praktik (Szczepanski, 2008, s.23-24, 53, 2011).

Utomhuspedagogikens didaktiska identitet och särart och därmed platsperspektiv, specificeras av förhållandet att den fysiska natur- och kulturmiljön utgör ramverket för lärandets innehåll. Argumentationen för ett platsperspektiv rymmer även ett undervisningstema, ett innehåll och ett sätt att lära. Det direkta mötet med platsen, lärmiljön beskrivs av Dahlgren och Szczepanski (1998):

Outdoor education would be one of few - if not the only - examples of an education that is defined by an expression stating the location of education, its where (s.37).

\section{Platsbegrepp - geografiskt, kognitivt och emotionellt}

Ordet plats kan beskrivas på flera sätt. Den svenska Nationalencyklopedin definierar det som ett "område med välbestämt läge och begränsad omfattning, ibland mer eller mindre tänkt som en punkt” (NE, 2012). I det här aktuella sammanhanget används det om avgränsade miljöer som kan nyttjas för pedagogiska ändamål utomhus. Begreppet platskänsla, sense of place, används för att belysa platsrelationen i en vidare bemärkelse - som en del av den kulturella identiteten, ett uttryck för ett starkt personligt förhållande till miljön, som i ett vidare perspektiv kan omfatta en hel region, ett land eller en nation (Lennon et al., 2001).

I ett skolsammanhang kan en känsla för platsen relateras till skolans närmiljö och leda fram till "en lokalhistorisk, ekologisk, social och fysisk förankring i det utvidgade pedagogiska rummet" (Szczepanski, 2008, s.58). Skillnaden mellan plats och område kan i det här sammanhanget sägas bestå i att platsen är mer avgränsad och identitetsskapande - laddad med emotionella minnen och erfarenheter. Begreppet område är diffusare och karakteriseras av mer opersonliga referenspunkter (Lundgren, 2006). Så här beskriver Tuan (1974) den mångsidiga platsrelationen mellan människa och fysisk miljö:

Topophilia takes many forms and varies greatly in emotional range and intensity. It is a start to describe what they are: fleeting visual pleasure; the sensual delight of physical contact; the fondness for place because it is familiar, because it is home and incarnates the past, because it evokes pride of ownership of creation (s.246).

Att märka är att platsbegreppet topos (grek. 'plats') inte enbart associeras till geografiska platser, utan också till mentala, kognitiva miljöer - mentala landskap. Upplevelsen av de objekt som utgör rummet kan alltså beskrivas som ett känslospel mellan upplevelse, perception och begreppsbildning, en "jag - plats relation" som kan sammanfattas i begreppet topofili. Ett "icke definierat rum" blir en plats med innehåll om man får en relation till den, lär känna den och laddar den med mening (ibid.).

Tuan talar om platsens kulturella identitet och dess upplevda betydelse, sinnligt lika väl som mentalt, "mindscape", om platserfarenhet som ett resultat av en integrerad kognitiv och fysisk upplevelse kopplad till landskapet, "landscape" (Tuan, 2005). Brusman (2008) tar också upp begreppet mindscape. Han definierar detta som ett medium genom vilket människans uppfattningar av en plats gestaltas i minnen och erfarenheter: "Ett mindscape är ett kognitivt landskap, förankrat i de fysiska strukturerna" (s.199). Båda refererar till plats- erfarenhet i en kognitiv - mindscape - och i en fysiskt upplevd erfarenhet - landscape.

Ett annat platsbegrepp i skolpraktiken är ställe (NE, 2012) ofta specificerat med ett visst innehåll eller viss funktion - badställe, smultronställe, svampställe. Begreppet är vanligen relaterat till en mer personlig upplevelse och till vad man gör och hur stället används, dvs. ett innehåll och ett görande, 
vilket fokuserar de didaktiska vad- och hur-frågorna. I sin pedagogiska kontext blir begreppet ställe ett exempel på markanvändning t.ex. odling - NO-ämnen, konstruktion - teknikämnet.

\section{Plats - lärande och undervisning}

I antologin Place-Based Education in the Global Age: Local Diversity belyses såväl platsmedvetenhetens rums- och tidsdimension, det kulturella och historiska minnet, naturkontaktens betydelse, som begreppet platslöshet, "placelessness", dvs. förhållandet att en direkt relation till platsen saknas (Gruenewald \& Smith, 2008). Det hävdas här att många lärare saknar egna närmiljörelationer och därmed också möjlighet att knyta an till lärmiljöer utomhus i undervisningen. Författarna reflekterar även kring återanvändandet av naturen, till ett liv i samklang med andra arter, "reinhabitation", till återerövringen av känslan för platsen, historiskt, kulturellt, ekologiskt och socialt (ibid.). Erfarenheten visar att platsmedvetenhet motverkar psykosocialt förtryck och skapar möjlighet att använda kulturella olikheter som pedagogiska tillgångar, "decolonization” (Gruenewald, 2003a, b). Denna känsla för platsens pedagogiska möjligheter (Lundgren, 2006; Knapp 1996) i kombination med "sense of place", i form av kulturell lyhördhet, demokratisk delaktighet, medvetande om olika miljöers globala dialektik belyses av flera forskare (Sobel, 2004; Smith, 2002; Hart, 1997). Med den globala dialektiken avses en vidgad förståelse kring ekologi, hållbar utveckling och social platsrelation i natur och samhälle genom ämnesintegration och miljötematik.

Betydelsen av en platsinteraktion i relationen mellan medvetandet och skolans fysiska rum påtalas från olika håll (Johansen, Lorentzen, Selander \& Skyum-Nielsen, 1997; Kampman, 2006; Kirkeby, 2006). Platsens budskap kan förmedlas genom textbaserad praktik i form av faktabeskrivningar, men också genom icke textbaserad praktik i form av upplevda dofter, smaker, ljud och taktila stimuli som kan vara svåra att verbalisera i ett undervisningssammanhang (Szczepanski, 2008). von Wright (2011, s.171-179) väcker också tankar kring platsens pedagogik, materialitet - inkänning - kommunikation, i mötet med den pedagogiska situationen och dess konsekvenser för meningsskapande aktiviteter. Neisser (1994) lyfter fram vikten av sinnenas interaktion med den fysiska omgivningen. I argumentationen för platsinteraktion framhålls den "mjuka" funktionalistiska arkitekturens större och bredare pedagogiska möjligheter att utmana den lärandes fantasi. Den hårda funktionalismen låser lärandet i striktare form (ibid. s.392-407). Den fysiska miljön fungerar i allmänhet som en katalysator i lek och lärande. Detta gäller också platser som inte är sanktionerade som lärmiljöer inom givna ramar (Fjørtoft, 2000; Grahn, Ekman, Lindblad, Mårtensson \& Nilsson, 1997; Grahn, 2003; Mårtensson, 2004; Åkerblom, 2005).

Med utgångspunkt i reflektioner av detta slag diskuterar Moser (2007) huruvida lärorummet i sin pedagogiska kontext kan förstås som ett läromedel, en text. Han framhåller att så är fallet, men att individens eller gruppens förmåga att läsa denna text är beroende av erfarenhetsbakgrund. Detta resonemang relaterar han till Skyum-Nielsen (1995) som hävdar att begreppet text kan täcka ett komplex av betydelser som är verbala, paraverbala och icke verbala. I tolkningsförmågan integreras enligt Moser (2007) både den kroppsliga fysiska upplevelsen av lärmiljön och erfarenheten av platsen som läromedel. Moser tar även upp "uteskole"-konceptet, där mer eller mindre natur- och kulturpräglade, platsbundna utomhusmiljöer ges en ökad betydelse i lärprocessen (jfr Dahlgren et al., 2007; Lundegård, Wickman \& Wohlin, 2004).

Sandberg (2009) redogör för de faktorer som är av betydelse för barn och ungdomars naturkontakt i stadsbebyggelse: föräldrarnas vanor och normer, tillgång till natur - obebyggd mark, skolans och förskolans förhållningssätt till utevistelse, samt tryggheten i bostadsområdet. Även Hyllested (2007) framhåller naturkontaktens och de autentiska miljöernas betydelse. Liknande tankegångar finner man också hos Andersson (2008), som bl.a. beskriver möten mellan arkeologer och elever och lärare på lågstadiet, där de arkeologiska fynden presenterades i klassrummet, medan själva utgrävnings- 
platsen inte besöktes. Westlund (1996) argumenterar dessutom för behovet av en mer flexibel och mindre inrutad tidsanvändning som kan öppna för studiebesök och ett mer tematiskt arbetssätt.

Jordet $(2007,2011)$ visar att utomhus- och inomhusundervisning kan komplettera varandra och som didaktisk undervisningsmodell stärka det erfarenhetsbaserade ämnesperspektivet. Mygind och Herholdt (2005) pekar på att ämnesmässiga, hälsorelaterade och sociala vinster kan erhållas om "uteskole" och klassrumsundervisning kombineras. Platsen kan ges både en organiserande och strukturerande, kontrollerande funktion (jfr Ceppi \& Zini, 1998; Moser \& Dudas, 2007; Zini \& Zoboli, 2002). Att notera här är skolans organisation med normen att på avstånd undervisa om fenomen, begrepp och processer, istället för att förlägga platsen för undervisningen $i$ den miljö där de förekommer (Lundgren, 2006):

Men aldrig att han tog ut oss i naturen, aldrig att han i undervisningen kom in på stadens märkliga belägenhet. Det verkade finnas ett oöverstigligt gap mellan undervisningen om naturen och den säregna natur som fanns strax utanför biologisalen. Det mentala avståndet var större än det rumsliga (s.254).

\section{Plats och miljömedvetenhet}

I Hutchinsons (2004) kunskapsöversikt beskrivs behovet av ett utvidgat läranderum och skapande av en "lokal platskänsla". Det framhålls här att barns och ungdomars mentala landskap blivit allt mer begränsat av standardiserade läroplaner, television och dataspel, vilket resulterat i färre möten med utomhusbaserade närmiljöer. Han redogör också för olika konkurrerande utbildningsperspektiv av betydelse för ett helhetslärande. Här tydlig- och synliggörs begreppet platskänsla som ett lärande för ökad miljömedvetenhet, social rättvisa, mänskliga rättigheter och kunskap om globaliseringens villkor och effekter.

I Magntorns (2007) undersökning kring ekologisk läsförmåga, "läsa landskap" (ecological literacy), och begreppsförståelse beskrivs betydelsen av att förstå sammanhang och relationer i sin rätta kontext. I en av sina fyra delstudier visar han på behovet av en nära kroppslig, fysisk relation till naturlandskapet för att förstå ekologiska sammanhang (ibid. Paper IV, s.76). Magntorn betonar också naturkontaktens betydelse för ekologisk begreppsförståelse. Liknande slutsatser kring naturkontaktens betydelse för en vidsyntare samhällssyn och ett större miljöengagemang presenteras av Fouhey och Saltmarsh (1996), Thomashow (1996) samt Wickenberg (1999).

I en reflektion kring utomhusundervisning fastslog redan Sharp 1943 (s.363-364) att lärandets innehåll bör anpassas till den plats som kan anses bäst lämpad, oavsett om det är inom- eller utomhus. Det han främst vände sig emot var skolans abstrakta undervisningssammanhang, som ofta skilde sig kraftigt från elevens vardagserfarenheter. Så sent som 2010 påtalar Bentsen lärares kunskapsbrister om udeskoleundervisning:

To summarize, there seems to be a gap of knowledge concerning udeskole teachers' use of and preferences for green space, place-based constraints to outdoor teaching and how green space managers can facilitate teachers and pupils in their outdoor learning activities (Bentsen, 2010, S.21).

\section{Platsens innebörder - en sammanfattning}

Ett genomgående mönster i ovanstående kunskapsöversikt är betoningen av en personlig, autentisk fysisk platserfarenhet. Den kroppsliga sinnliga interaktionen utgör en viktig grund för förståelsen av lärande och undervisning utomhus. Vidare argumenteras för ett erfarenhetsbaserat lärande och att utomhus- och inomhusundervisningen kan komplettera varandra. Man talar om betydelsen av platsinteraktion, platsen som text och läromedel för att förstå sammanhang och relationer i lärande 
och undervisning. Det platsbaserade perspektivet kopplas också till ekologisk läsförmåga, ”ecological literacy", till ett miljöengagemang som kan leda till ökad miljömedvetenhet, ett hållbart samhälle och kunskap om globalisering. I denna sammanställning påpekas också lärares kunskapsbrist vad avser utomhusundervisning och närmiljörelationer, som leder till en benägenhet att ofta på avstånd och i abstrakta termer undervisa om begrepp, fenomen och processer. Ur ett pedagogiskt perspektiv blir därmed var-frågan och platsanvändningen utomhus ofta osynliggjord och tagen för given.

\section{METODOLOGISKA ÖVERVÄGANDEN}

Den metodologiska ansatsen i denna studie är fenomenografisk, vilket innebär att den även är induktiv och kvalitativ. Det fenomenografiska forskningsperspektivet syftar till att beskriva verkligheten såsom den uppfattas och tolkas av människan (Uljens, 1989). Ansatsen utgår från en människa omvärldsrelation som vilar på en icke-dualistisk ontologi, dvs. förutsättningen att den enda omvärld som är meningsfull är den av människan uppfattade. Men människors sätt att uppleva sin omvärld varierar i kvalitativt avseende. Det fenomenografiska projektet består i att beskriva dessa olika sätt att förstå och uppfatta fenomen i omgivningen, "de empiriska subjektens sätt att erfara verkligheten" (Uljens 1998, s.124). Pedagogiken är på samma sätt beroende av vad undervisande lärare föreställer sig eller uppfattar att lärande utomhus innebär. Utomhuspedagogiken kan för den enskilda läraren följaktligen se ut på många olika sätt (jfr Szczepanski, 2008). Avsikten med denna studie är inte att närmare uttala sig om grunden till dessa skillnader. Syftet begränsas till att beskriva å ena sidan lärares uppfattningar av det platsrelaterade lärandet utomhus, och å andra sidan de kvalitativa skillnader som kan urskiljas inom respondentgruppen. Det primära forskningsintresset är inte heller att avgöra hur frekventa de olika uppfattningarna är, utan att söka och identifiera nyanser, skillnader och variationer i beskrivningar av fenomenens skiftande natur och hur de framträder (jfr Larsson, 1986, 2005).

\section{Studiens avgränsning och karaktär}

Undersökningen baseras på intervjuer med 19 lärare i en sydsvensk kommun läsåret 2008/2009. Syftet är närmare bestämt att ta reda på vilka uppfattningar som kan iakttas och urskiljas bland lärarna i undersökningsgruppen avseende platsens betydelse för lärande och undervisning. Begreppsapparaten kring den fysiska lärmiljön utgår från lärarnas egna erfarenheter och förförståelse. Beträffande valet av en fenomenografisk ansats, se t.ex. Alexandersson $(1994,1998)$.

\section{Respondenternas skolsammanhang}

I fokus för studien ligger en f-6-skola, förskoleklass t.o.m. årskurs 6 med ca 250 elever, en "autodidaktskola" (i utomhuspedagogiskt avseende) där fem lärare på eget initiativ satt sig in i och tillämpar utomhuspedagogiska metoder. Skolbyggnaden och skolgården med naturmark gränsar till ett skogsområde. I närområdet finns en "skolskog" på ca 1 hektar med pedagogiska ämnesrum som varierar efter årstidsväxlingarna. Det är främst elever och lärare på mellanstadiet som har byggt upp och använder sig av skolskogen. Respondenterna från denna skola är till antalet tio.

Åtta respondenter representerar två andra skolor i kommunen. Bland dessa har tre tidigare arbetat på autodidaktskolan. En respondent är verksam som skolpolitiker. Av totalt 19 respondenter som betecknas med nummer 1-19 arbetar tretton som lärare, fem som skolledare och en som skolpolitiker. Samtliga har lärarbehörighet och undervisningserfarenhet. Följande skolformer är representerade: förskola, grundskola, förskoleklass, låg- och mellanstadium och gymnasieskola. Formell utbildning i utomhuspedagogik saknas. Åldersspannet omfattar 30-64 år och könsfördelningen är tretton kvinnor och sex män. Respondenterna valdes med hjälp av skolornas rektorer, ett så kallat "bekvämlighetsurval”, som är en praktisk metod för att få tillgång till en population (Trost, 2005). Urvalet som helhet gjordes för att få en variation i uppfattningar inom respondentgruppen, vilket är centralt i en fenomenografisk studie (Marton \& Booth, 2000). 


\section{Databildning}

Kvalitativa, semistrukturerade intervjuer med öppna frågeställningar och låg grad av standardisering valdes för att få så stora variationsmöjligheter i svaren som möjligt. Forskaren är inte styrande, men sätter ramar och för samtalet vidare (Holme \& Solvang, 1997). Det skall också framhållas att intervjupersonerna ses som respondenter i betydelsen att de svarar för sig själva och uttrycker sina uppfattningar, till skillnad från en informant som rapporterar till forskaren om sina observationer. Intervjuerna omfattade i genomsnitt ca 60 minuter och skedde i så likartade kontexter som möjligt för att öka jämförbarheten i materialet (Kvale, 1997).

En pilotintervju genomfördes som test av frågeställningarnas hållbarhet före själva huvudstudien. De inspelade intervjuerna transkriberades i sin helhet. I avsikt att illustrera olika fysiska lärmiljöer, främst utomhus, utdelades vid intervjutillfället en intervjuguide med öppna frågeställningar (se nedan) och fotografier av skolmiljöer, stadsmiljöer, parker och torg, vattenmiljöer, industrimiljöer, skogsmiljöer, ängs- och hagmark. Avsikten med bild-materialet var att synliggöra den didaktiska var-frågan i anslutning till intervjufrågorna.

Ramverket utgjordes av följande intervjufrågor: Vad är utomhuspedagogik för dig, vad är kunskap för dig, hur undervisar du om miljöfrågor och varför undervisar du, som du gör? Efter genomförandet av 19 intervjuer bedömdes att en så kallad "teoretisk mättnad" hade uppnåtts (Glaser \& Strauss, 1967).

\section{Analysförfarande}

Arbetsprocessen har följt ramarna för den fenomenografiska analysmetoden (se även Hayes, 2000). De transkriberade intervjusvaren användes som underlag för analysen, som genomfördes i sex steg:

1. Olika nyckelord i viktiga textpartier angavs i marginalen för att ge ett helhetsintryck.

2. Utsagorna urskildes och sorterades i olika beskrivningskategorier baserade på möjliga mönster - likheter eller skillnader - för att kunna identifiera olika uppfattningar.

3. En tydligare bild av textens innehåll (kärnan i uppfattningarna) utkristalliserade sig efter ytterligare genomläsning av intervjuerna.

4. Etikettering, namngivning och beskrivning av vad som är utmärkande för respektive kategori genomfördes.

5. Identifiering och systematisering av lärarnas uppfattningar presenterades i ett kategorisystem omfattande nio kategorier - med fokus på underliggande didaktiska aspekter.

6. Utifrån kategorisystemet urskildes fyra platsrelaterade perspektiv (jfr Uljens, 1989, s.50-51).

Marton och Booth (2000, s.163) ställer upp tre kriterier för egenskaper som beskrivningskategorier bör omfatta, nämligen att de säger något tydligt om undersökningens fenomen, att de är logiskt relaterade till varandra och att de begränsas till antalet så att den kritiska variationen kan ringas in. Dessa tre kriterier har varit vägledande i analysen (jfr Larsson, 1986, 2005). I presentationen av kategorierna anges under varje kategori citat som är typiska för innehållet. Kategorisystemet, som är ett resultat av analysen, utgör ett utfallsrum inom vilket kategoriernas inbördes relationer kan beskrivas (jfr Uljens 1989, 1998). För att säkerställa noggrannheten i kategoriseringen av intervjumaterialet har samråd och förhandling med medbedömare ägt rum i enlighet med s.k. "negotiated concensus", det vill säga en procedur i vilken forskarna först var och en för sig föreslår sin egen tolkning och kategorisering av data och därefter kommer fram till en gemensam kategorisering (se Beerman, Dahlgren, Diwan, Tomson \& Walström, 1997, s.224-225). I föreliggande studie var graden av samstämmighet eller interbedömarreliabilitet mellan forskarna ca $70 \%$, vilket är relativt högt (jfr Alexandersson, 1994, s.111-136). 
Med utgångspunkt i lärares uppfattningar av platsens betydelse för lärande och undervisning utomhus - det fenomen som här skall utforskas och beskrivas - framträder kategorier som kan vara plats-, innehålls- eller förklaringsorienterade (jfr Kroksmark 1987, 2007; Larsson 1986, s.36). De aspekter var, vad, hur och varför som valts ut i den kontextuella analysen utgör uppfattningarnas mening eller innebörd (jfr Marton \& Booth, 2000). I utfallsrummet till denna analys framträder den didaktiska var-frågan som mönsterbildande för de beskrivningskategorier som utkristalliserats.

\section{Metodologiska reflektioner}

Genomförande av intervjuer inom forskarens eget verksamhetsområde, som i detta fall kan innebära en risk för skevhet i resultatet. Det är inte alltid så lätt att uppfatta en eventuell egen påverkan. Samtidigt kan kunskap om och erfarenhet av de ramfaktorer som påverkar, samt ämnesteoretisk innehållskompetens, vara en fördel (Alexandersson, 1994; Kvale, 1997). I denna studie har forskarens förkunskaper inom området varit centrala för att förstå respondenternas utsagor och identifiera och formulera underliggande kategorier.

Resultatet från studien kan inte heller utan vidare generaliseras utöver den speciella undersökningskontexten, i det här fallet den plats för lärande och undervisning där studien har genomförts. Larsson (2009) argumenterar dock för en pluralistisk inställning (mångfald i uppfattningar) i sin tolkning av den empiriska generaliseringsproblematiken i kvalitativa studier - resultaten kan ha ett generellt värde på olika sätt. En likartad kontext betyder till exempel inte med nödvändighet att resultaten är användbara i en annat liknande sammanhang, men det kan vara så. Likheter i kontexter indikerar att det finns ett handlingsutrymme, en pragmatisk potential i relationen till det empiriska resultatet. Exempelvis kan resultaten från denna studie ge en förståelse kring platsens betydelse för lärande och undervisning. Denna förståelse kan bidra till och påverka ett didaktiskt tänkande och tillämpning i andra pedagogiska sammanhang i andra kommuner etc. Generaliseringen är dock löst relaterad till sin kontext, så till vida att forskaren inte säkert kan förutsäga i vilka fall som tolkningen är användbar. Användbarheten framträder när resultaten tillämpas i nya sammanhang. Det går därmed inte att på förhand veta var kategorierna kan få en mer generell användbarhet.

\section{Etiska aspekter}

I materialet är både skolor och lärare avkodade, texterna innehåller enbart anonyma utsagor. Till grund för studiens utformning ligger Vetenskapsrådets etiska principer (2006) nämligen: informationskravet, samtyckeskravet, konfidentialitetskravet och nyttjandekravet. Anteckningarna från intervjuerna och ljudbanden kommer att bevaras (Vetenskapsrådet, 2011, s.70-71).

\section{RESULTAT OCH ANALYS}

Analysen av utomhuspedagogikens platsrelation utgår från forskningsfrågan: vilka uppfattningar har lärare av platsens betydelse för lärande och undervisning utomhus? Resultatet från intervjuundersökningen beskrivs nedan utifrån identifierade svarskategorier, A - I, med korta summeringar och signifikanta intervjuutdrag för att beskriva innehållet. Utifrån den fenomenografiska analysmetoden identifieras respondenternas uppfattningar kring platsens betydelse för lärande och undervisning utomhus genom nio huvudkategorier, vilka tillsammans utgör studiens utfallsrum: att upptäcka andra lärmiljöer än klassrum, att använda större öppna ytor, att utnyttja en rumslig mångfald, att främja växelverkan mellan olika lärmiljöer, att förena teori och praktik, att tillämpa ett kroppsligt, sinnligt lärande, att skapa variationsrika möten med olika fenomen, att skapa en utomhusplattform för miljöarbete samt att disponera tiden på ett friare sätt. 


\section{A. Lärande och undervisning utomhus innebär möjligheter att upptäcka andra lärmiljöer än klassrum}

Exempel: lärare 6, 8, 13, 15 .

Fokus i denna kategori ligger på utomhusundervisningens var-aspekt, medan vad- och hur-aspekten finns i bakgrunden. I korthet handlar det om att i ett pedagogiskt syfte identifiera olika lärmiljöer var, innehåll - vad och olika sätt att lära - hur, på skolgården, i skolskogen och andra grönområden i skolans närhet. Skolgården uppfattas som en möjlighet och ett första steg att komma utanför klassrummets undervisnings- och lärmiljö.

Egentligen så rör det sig bara om att man är utomhus och hittar andra miljöer att lära sig saker i, om man lämnar klassrummet och skolans miljö, tycker jag (6). Det innebär ju inte att man behöver vara långt borta, utan det kan vara i närheten och det kan vara skolgården, helt enkelt (8). Det handlar om att använda utemiljön i ett pedagogiskt syfte och att hitta andra lärovägar (13). Jag kan se möjligheter med utomhuspedagogik genom att jämföra det med att bo i ett rum och kök, och att få ett rum till och upptäcka att man kan ha andra verksamheter där (15).

\section{B. Lärande och undervisning utomhus innebär möjligheter att använda större öppna ytor} Exempel: lärare 4, 6, 17.

I denna kategori framhålls platsens betydelse, var-aspekten, för tillgången till större öppna ytor i utomhusundervisningen på skolgården. Vad-aspekten kopplas till skolans ämnen, t.ex. teknik och bild. Hur-aspekten beskriver en ökad konkretionsgrad och pedagogisk valfrihet. Metoden som är relaterad till en större öppen yta varför-aspekten synliggörs bl.a. i utsagan kring momentet "utväxlingar" i teknikämnet. Förståelsen för ämnesrelaterade begrepp kan levandegöras på ett friare sätt utomhus.

Vi använder de här ytorna på skolgården för olika typer av farkoster, "råttfällebilar" och "raketbilar”. Att jobba med bilar ger eleverna en förståelse för utväxlingar. Ja, det är ett bra teknikområde (4). Om man har bildunder-visning i klassrummet har man sitt bord och kanske golvet som man kan vara på. Men här gör vi en bild som är tjugo meter, du har inte de yttre begränsningarna och man kan se det både i bilden och i textilen (6). Det som är skillnaden det är att det handlar om en större yta utomhus, vilket ger mera frihet (17).

\section{Lärande och undervisning utomhus innebär möjligheter att utnyttja en rumslig mångfald}

Exempel: lärare 1, 2, 3 .

Utomhusundervisningen ger möjlighet att ta vara på var-aspektens naturpräglade rumsliga variation i skogen. Den rumsliga mångfalden innebär att lärmiljön kan relateras direkt till lärandets objekt och fenomen. Vad- och hur-aspekten finns i bakgrunden och handlar om att välja ut och bygga upp pedagogiska rum (ämnesrum) i undervisningen. Den rumsliga mångfalden innebär att hur-aspekten upplevs som betydelsefull både för fantasi och kunskapsbildning. Fantasin stimuleras av element hämtade från naturens rumsliga mångfald.

Utomhuspedagogik för mig är att ha tillgång till en hel skog, det är obegränsat som jag tänker. Men skall man göra någonting bra av det, så måste man hitta ett ställe där man kan få vara. Det är ju att hitta ett annat rum för lärande, som jag ser det (1). Det finns en sådan mångfald därute av kunskaper i ämnesrummen: slöjd, drama, svenska, engelska och matematik (2). Mångfald, är ett uttryck som jag vill använda, eftersom jag ser en mångfald av rum som är oslagbara för att sätta fantasin i rörelse och befästa kunskaper (3). 


\section{Lärande och undervisning utomhus innebär möjligheter att främja växelverkan mellan olika lärmiljöer}

Exempel: lärare 2, 11, 15 .

Var-aspekten framträder genom betoning av växelverkan mellan inomhusundervisning och utomhusundervisning som ger tillgång till flera platser för lärande. Vad-aspekten, det som skall läras ut, kopplas till platsen. I denna kategori uppfattas utomhuslärande, dvs. hur-aspekten, erbjuda andra former av lärande än den rent textbaserade praktiken, utan att vara ett självändamål.

Det är det praktiska som man skall lägga mest tyngdpunkt på, eftersom det är svårare att i klassrummet jobba på det sättet (2). Om man är både "inne och ute" så ger det barnen större möjligheter till flera platser för sitt lärande (11). Jag eftersträvar inte att det skall bli mera teoretiskt i skogen, som att ta ut böcker och sitta där och djupplugga in saker. Däremot eftersträvar jag att det skall bli mera praktiskt även inomhus. Man kan ha samma kunskaper och mål utomhus, men man måste göra det på ett annat sätt (15).

\section{E. Lärande och undervisning utomhus innebär möjligheter att förena teori och praktik}

Exempel lärare: 5, 11, 13 .

I denna kategori framträder vad-aspekten genom möjligheten att förena teoretisk och praktisk kunskap i utomhusundervisningen. Hur-aspekten i praktisk handling (metoden) uppfattas ge ökad förståelse som ett komplement till den teoretiska undervisningen. Var-frågan finns i bakgrunden. Underliggande tankar till varför-aspekten i kopplingen mellan teori och praktik är inte fullt ut implementerade i undervisningen.

Jag ser på lärandet som att det teoretiska och praktiska går hand i hand, och att det är ett komplement till varandra, det här med inomhus och utomhus (5). Jag känner att det hör ihop om man får prova teorin och det praktiska kunnandet. Om du bara får teorin så kanske du inte förstår, utan man måste också prova det praktiskt och då blir det ett större kunnande (---). Du kan nog ha teori ute i skogen också och det praktiska inne, så det kan vara omvänt. Det beror nog på hur man lägger upp det (11). Teorin behöver ju inte alltid komma före praktiken som det ofta gör i skolan, utan en teoribildning kan väl också uppstå i ett praktiskt sammanhang, om jag säger så (13).

\section{F. Lärande och undervisning utomhus innebär möjligheter att tillämpa ett kroppsligt, sinn- ligt lärande}

Exempel: lärare 4, 6, 9.

Kategorin kopplas till betydelsen av naturliga sinnesintryck i relevanta sammanhang utomhus. Huraspekten ligger i förgrunden och kommuniceras genom sinnesintryck och kroppsrörelse. Var-aspekten och vad-aspekten finns i bakgrunden och kopplas till olika språkliga uttryck såsom bildspråk och kroppsspråk. Kroppsrörelsen som en del av ett sinnligt lärande finns med men berörs bara på ett ytligt plan.

Det är ett lärorum där man har större möjlighet att konkretisera olika ämnen och där man också öppnar sinnena på mottagaren (4). Det är en sak att sitta och prata om det i en skolsal än där nere i mossan eller att bara titta på molnen och se hur de rör sig. Det är ju konkret direkt, sinnena blir större och helheten bidrar (---). Vi har bildspråk-, kroppsspråk och osynliga språk som vi pratar med och sådant lär vi oss mera av om vi inte sitter stilla på en stol (6). Ja, utomhuspedagogik för mig är att vara utomhus och röra på sig och uppleva naturen med alla sinnen. Att uppleva med hela kroppen, tycker jag är jätteviktigt (9). 


\section{G. Lärande och undervisning utomhus innebär möjligheter att skapa variationsrika möten med olika fenomen}

Exempel: lärare 4, 7, 13.

Vad- och hur-aspekterna ligger i förgrunden i denna kategori. Innehåll och metod kopplat till platsen innebär variation i mötet med olika fenomen i lärandet. Varför-aspekten synliggörs i utsagan kring momentet "sammanfogning" i slöjdundervisningen för att visa på skillnader i förståelse och färdighet. Spår av mänsklig aktivitet genererar didaktiska frågeställningar.

Jag har försökt att få eleverna att förstå hur man sammanfogar utomhus, allting är ju "runt” ute i skogen och jag har fått dem att förstå skillnaden mot inne i slöjdsalen, där allting är kvadratiskt och rektangulärt (4). Man tittar på landskapet, stenarna och hur de ligger: varför ligger de så här, har det bott folk här och vad levde de av? Det är mycket som väcks till liv, funderingar om vad som finns här: vad är det för träd, varför står det ett körsbärsträd mitt ute i skogen, eller varför växer den här blomman här? (7). Det finns många saker att göra här som botanik, att använda träden, och blommorna och insekterna för att studera skillnader och olikheter, och hur de samverkar (13).

\section{H. Lärande och undervisning utomhus innebär möjligheter att skapa en utomhusplattform för miljöarbete}

Exempel: lärare 1, 3, 13 .

Sättet att arbeta med miljöfrågor, hur-aspekten står i centrum i denna kategori. Lärarna uppfattar att miljöundervisningen konkretiseras genom förstahandserfarenheter i möten med den fysiska närmiljön, var-aspekten. Vad-aspekten exemplifieras genom naturvetenskapliga processer i naturen. Odlingsprojekten beskrivs i imperfekt och är vilande.

Det är omöjligt att undervisa om miljön i ämnet kemi utan att gå ut i naturen och mäta PHvärden och ta prover på snön, anser jag (1). Vi jobbade med Grön Flagg och jag var med och drev ett växtprojekt, och vi fick den gröna flaggan. Vi drev upp plantor för att se vad som hände från frö till planta, hela processen. Det blev en hel del utomhus, ja det blev det (3). Det handlar ju både om att använda sig av ett uterum och att arbeta med vanliga ämnen för att studera miljön och vår miljöpåverkan (13).

\section{Lärande och undervisning utomhus ger möjligheter att disponera tiden på ett friare sätt} Exempel: lärare 2, 3, 6.

Ett friare sätt att disponera undervisningstiden uppfattas öka fokuseringen och koncentrationsförmågan i lärprocessen över tid. Naturen uppfattas i sig minska stressen och borgar för ett annat förhållningssätt till tid och lärande. Den schemabundna tidsstrukturen luckras upp vid undervisning utomhus, och undervisningens uppläggning och genomförande påverkas, dvs. vad- och hur-aspekten ses som likvärdiga. Denna påverkan utifrån platsen utomhus framträder i relation till klassrummets uppfattade begränsningar av tiden. Var-aspektens tidsrelation finns i förgrunden och möjliggör en friare och flexiblare tidsanvändning i undervisningen.

Utomhus făr eleverna en förståelse för att vissa saker tar längre tid för att lära sig, det går inte på en timme (2). Tiden upphör i naturen och det är ett jätteplus, tycker jag. Just det här att man slukas av tiden, det är de gånger man mår bra som man inte tänker tid. Inomhus vill barnen lära sig direkt, ute i skogen däremot har de mera tålamod för att lära sig, de behöver inte den direkta feedbacken (3). Det är mera avstressat att vara utomhus, än att vara jagad av signaler och tidsbegränsningar (6). 


\section{Summering av resultaten}

Analysen av undersökningens empiriska material visar att platsrelationen, på grundval av respondenternas uppfattningar om platsens betydelse för lärande och undervisning utomhus, kan definieras utifrån fyra perspektiv med fokus på var-aspekten nämligen:

1. Rumsperspektivet, som relateras till möjligheterna att upptäcka andra lärmiljöer och pedagogiskt användbara ställen med både rumslig mångfald och större öppna ytor samt främjandet av växelverkan mellan dem.

2. Kunskapsperspektivet, som relateras till möjligheterna att förena teori och praktik, tillämpa ett kroppsligt sinnligt lärande, samt att skapa variationsrika möten med olika fenomen. Reflektion i handling i andra lärmiljöer än klassrum kan dessutom generera tankar om relationen mellan teori och praktik.

3. Miljöperspektivet, som relateras till möjligheterna att skapa en utomhusplattform för miljöarbete. Miljötematiken kan konkretiseras via förstahandserfarenheter i NO-ämnen och tematiska växtodlingsprojekt där skolans alla ämnen ingår.

4. Tidsperspektivet, som utomhus relateras till möjligheterna att disponera tiden på ett friare sätt. Skolans schemabundna tidsstrukturer uppfattas luckras upp i det platsrelaterade naturmötet vilket upplevs minska stressnivån.

Studien beskriver respondenternas uppfattningar av platsens didaktiska betydelse för lärande och undervisning. Lärande och undervisning utomhus anses innebära möjligheter att utveckla platsrelationen utifrån fyra perspektiv: rums-, kunskaps-, miljö- och tidsperspektivet, vilka kommer till uttryck och speglas i de olika kategoriernas innehållsmönster. Dessa "tematiserade perspektiv" har utkristalliserats utifrån de didaktiska aspekterna var, vad, hur och varför med deras olika nyanser och variationer. I det totala utfallsrummet står rumsperspektivet, var-aspekten, i förgrunden i kategorierna A, B, C, D och I. Kunskapsperspektivet, vad- och hur-aspekten, varierar i styrka i kategorierna E, F, G och I. Miljöperspektivet, var-, vad- och hur-aspekten, som framträder i kategori H, är svagare förankrat i lärarnas utsagor. I tidsperspektivet, kategori I, uppfattas skillnader i förhållningsätt till tidsstrukturens begränsningar utifrån var- och hur-aspekten. Varför-aspekten framträder i respondenternas metodrelaterade uppfattningar i kategori B, G, men förekommer i övrigt sparsamt i materialet, däremot förekommer tankar om varför-aspekten se t.ex. kategori E.

\section{RESULTATDISKUSSION OCH IMPLIKATIONER}

Studien presenterar lärares uppfattningar av platsens betydelse för lärande och undervisning utomhus och resultatet visar på fyra platsrelaterade perspektiv kring utomhuspedagogik nämligen, rums-, kunskaps-, miljö- och tidsperspektivet. Om vi ser till forskning kopplad till begreppet plats och rummets betydelse i pedagogisk verksamhet uppvisar den en rik variation av infallsvinklar, vilket framgår både av mitt empiriska material och av tidigare studier (jfr Gruenewald \& Smith, 2008; Løvlie, 2007). Det råder däremot brist på forskning i ett platsrelaterat utomhusdidaktiskt sammanhang. I denna studie fokuseras detta i och med de fyra perspektiven, de identifierade kategorierna och de relaterade underliggande didaktiska aspekterna. I kategori B och C indikeras betydelsen av tillgång till stora öppna ytor på skolgårdar och närliggande skogsmiljöer med rumslig mångfald. Kanske kan här uppfattningen av användningen av närmiljön och skolgården som beskrivs i kategori A ses som en första fas i en utveckling och implementering av utomhusundervisning som inkluderar textbaserad praktik med sinnliga uttrycksformer i det omgivande landskapet, staden och samhället (jfr Szczepanski, 2008; Åkerblom, 2005).

I de olika kategorierna varierar var, vad- och hur-aspekterna i styrka, medan varför-aspekten förekommer sparsamt i hela materialet. Jag menar att detta tyder på en osäkerhet hos respondenterna att förklara varför man använder sig av vissa platser och därtill kopplade undervisningsmetoder, något 
som kan ha sin bakgrund i en svårighet att utifrån egna erfarenheter beskriva platsrelaterade lärandemoment och didaktiska frågeställningar i utomhusmiljön (jfr Wilhelmsson, 2012).

Ett framträdande drag i lärarnas uppfattningar av platsens betydelse för lärande och undervisning förefaller vara att utomhusmiljön, främst skogen i kategori C, D, E, F och G, upplevs som en pedagogisk möjlighet och ett komplement till klassrummets lärmiljö. Natur- och kulturspår i landskapet väcker didaktiska frågeställningar, kategori G. Det handlar här dels om att lära sig att läsa landskap utan mellanled som text och bild och dels om att i lärmiljön fokusera på praktiska och teoretiska aspekter av kunskapen (jfr Magntorn, 2007; Szczepanski, 2008).

De illustrerande citaten i kategori F visar hur undervisning utomhus uppfattas bredda de språkliga uttrycksformerna genom att integrera hela kroppen och rörelsen i lärandet. En möjlighet till platsrelaterad växelverkan mellan olika lärmiljöer och kombination av teori och praktik framträder i kategori D och E. Denna växelverkan leder in respondenternas tankar på relationen teori och praktik, och förenandet av praktiska och teoretiska kunskapsaspekter. Betydelsen av sådan växelverkan har framhållits inom tidigare forskning (se Bentsen, 2010; Jordet, 2010; Mygind \& Herholdt, 2005). Upplevelser i naturen uppfattas bana väg för en ökad och förstärkt sinnesupplevelse (jfr bl.a. Lundgren, 2006; Brusman, 2008). Mot bakgrund av dessa och andra studier argumenterar Brusman (2008), Moser (2007), Neisser (1994), Szczepanski (2008) och Tuan (2005) för vikten av en kroppslig, sinnlig integration med platsen under lärprocessen.

Utomhusundervisning upplevs också skapa möjlighet till förstahandserfarenhet i miljö-arbetet, kategori $\mathrm{H}$, medan mångfalden av ämnesrum utomhus uppfattas stimulera fantasin och befästa kunskapsbildning i kategori C. Möjligheterna att bedriva en framgångsrik miljöundervisning anses med andra ord som beroende av både tillgång till såväl ämneskopplingar som naturmiljöer där miljöpåverkan kan studeras (jfr Hutchinson, 2004; Thomashow, 1996; Wickenberg, 1999).

Respondenterna framhåller i kategori I betydelsen av att undervisningstiden kan disponeras på ett friare sätt i naturen och därmed minska stressen. Westlund (1996) har även i sin studie påtalat problemet med den inrutade lektionstiden som motverkar ett problembaserat, temainriktat arbetssätt.

Om platsens betydelse för undervisning och lärande i framtiden skall få en mer framträdande position behöver begreppet plats penetreras djupare. Analys av lärares uppfattningar om den utomhuspedagogiska praktiken är ett viktigt moment i en vidgad diskussion kring platsbegreppet. Detta ger mig anledning att avslutningsvis peka på några didaktiska och forskningsrelaterade implikationer kopplade till platsens betydelse för lärande och undervisning:

1. Den rumsliga mångfalden behöver utvidgas till att förutom skolgården och skogen även inkludera stadens utomhusmiljöer.

2. Kunskapen att "läsa landskap" behöver utvecklas i en utomhusplattform som bygger på en växelverkan mellan icke textbaserad- och textbaserad praktik i olika lärmiljöer.

3. Miljötematiken behöver stärkas i alla ämnen för ett långsiktigt miljöarbete i ett hållbart samhälle. 4. Skolans klassrumsbaserade tidsstruktur behöver luckras upp till förmån för en friare och flexiblare tidsanvändning som bl.a. kan skapa utrymme för en mer rörelseintensiv lärmiljö.

Som nämnts inledningsvis hävdade redan Lloyd B. Sharp (1895-1963) betydelsen av växel-verkan mellan olika lärmiljöer i undervisning och lärande:

That which ought and can be taught inside the schoolrooms should there be taught, and that which can best be learned through experience dealing directly with native materials and life situations outside the school should there be learned (Sharp, 1943, s.363-364). 


\section{REFERENSER}

Alexandersson, M. (1994). Den fenomenografiska forskningsansatsens fokus. I: B. Starrin, \& P-G. Svensson (Red.), Kvalitativ metod och vetenskapsteori (s.111-136). Lund: Studentlitteratur.

Alexandersson, M. (1998). Exempel på hur fenomenografin kan tillämpas i praktiken. I: A. Alcazar (Red.), Fenomenologi, fenomenografi och hermeneutik (s.37-47). Högskolan i Örebro. Örebro: Forum för humanvetenskaplig forskning.

Andersson, J. (2008). Skilda världar: Samtida föreställningar om kulturarvsplatser. Doktorsavhandling, Linköping, Studies in Arts and Science No. 453. Linköping: Linköpings universitet.

Beerman, B., Dahlgren, L. O., Diwan, W. K., Tomson, G., \& Walström, R. (1997). Changing Primary Care Doctors' Conceptions: A Qualitative Approach to Evaluation an Intervention. Advance in Health Science Education, 2 (3), 221-236.

Bentsen, P. (2010). Udeskole: outdoor teaching and use of green space in Danish schools. Doctoral dissertation, Copenhagen: University of Copenhagen, Faculty of Life Science Forest and Landscape.

Brusman, M. (2008). Den verkliga staden: Norrköpings innerstad mellan urbana idéer och lokala identiteter. Doktorsavhandling, Linköping Studies in Arts and Science No. 416. Linköping: Linköpings universitet, Tema kultur och samhälle.

Ceppi, G., \& Zini, M. (1998). Children, spaces, relations: Metaproject for an environment for young children. Reggio Emilia: Reggio Children Domus Academy Research Center.

Dahlgren, L. O., Edman, S., Grahn, P., Nelson, N., Schön, E., Sjölander, S., Strid, J. P., \& Szczepanski, A. (2007). Utomhuspedagogik som kunskapskälla: Närmiljö blir lärmiljö. Lund: Studentlitteratur.

Dahlgren, L.O., \& Szczepanski, A. (1998). Outdoor education: Literary education and sensory experience: An attempt at defining the identity of outdoor education. Linköping, Sweden: Linköping University.

Fjørtoft, I. (2000). Landscape as Playscape: Learning effects from playing in natural environment on motor development in children. Doctoral dissertation, Oslo: Norwegian University, University of Sport and Physical Education.

Fouhey, H., \& Saltmarsh, J. (1996). Outward Bound and community service learning: An experiment in connected knowing. The Journal of Experiential Education, 19(2), 82-89.

Glaser, B. G., \& Strauss, A. L. (1967). The Discovery of Grounded Theory: Strategies for Qualitative Research. Chicago: Aldine.

Grahn, P., Ekman, A., Lindblad, B., Mårtensson, F., \& Nilsson, P. (1997). Ute på dagis: Hur använder barn daghemsgården? Utformning av daghemsgården och dess betydelse för lek, motorik och koncentrationsförmåga. Alnarp: Movium, SLU.

Grahn, P. (2003). Trädgården: Tiden, lusten och varat. I: G., Blücher, \& G. Graninger (Red.), Finns det rum för barn? Stiftelsen Vadstena Forum - För samhällsbyggande (s.97-125).

Gruenewald, D. (2003a). The best of both worlds: A critical pedagogy of place. Educational Researcher, 32(4), 3-12.

Gruenewald, D. (2003b). Foundation of place: A multidisciplinary framework for place-conscious education. American Educational Research Journal, 40(3), 619-654.

Gruenewald, D. A., \& Smith, G. A. (2008). Place-Based Education in the Global Age: Local Diversity. New York: Lawrence Erlbaum Associates.

Hart, R. (1997). Children's participation: The theory and practice of involving young citizens in community development and environmental care. London: Earthscan, Unicef.

Hayes, N. (2000). Doing Psychological Research: Gathering and Analysing Data. Buckingham: Open University Press.

Holme, I. M., \& Solvang, B. K. (1997). Forskningsmetodik: Om kvalitativa och kvantitativa metoder. Lund: Studentlitteratur.

Hutchinson, D. (2004). A Natural History of Place in Education. New York: Teachers College Press, Columbia University. 
Hyllested, T. (2007). Når laereren tager skolen Ud af Skole. Doktorsavhandling, Roskilde: Danmarks Paedagogiske Universitet.

Johansen, E. B., Lorentzen, S., Selander, S., \& Skyum-Nielsen, P. (1997). Kunskapens tekster: jakten på den gode laerbok. Oslo: Universitetsforlaget.

Jordet, A. (2007).”Nærmiljøet som klasserum”: En undersøkelse om uteskolens didaktikk i et danningsteoretisk og erfaringspedagogisk perspektiv. Doktorsavhandling, Universitetet i Oslo.

Jordet, A. (2010). Klasserommet utenfor: tilpasset opplæring i et utvidet læringsrom. Oslo: Cappelen akademisk forlag.

Jordet, A. (2011). Klasserommet utenfor: Lærere og elever trenger et utvidet læringsrom. I: Education and Sustainability, Alternativa lärmiljöer, Utomhuspedagogik 5, 8-11 (upplaga Sverige). Malmö: Malmö högskola.

Kampman, J. (2006). Børn, rum og rummelighed. I: K. Rasmussen (Red.), Børns steder: Om børns egne steder og voksnes steder til børn (s.106-120). København: Billesø \& Baltzer.

Kirkeby, I. M. (2006). Skolen finder sted. Sbi (Statens Byggforskningsinstitut) Hørsholm: Danmark.

Knapp, C.E. (1996). Just Beyond the Classroom: Community Adventures for Interdisciplinary Learning. Charleston WV: ERIC Clearinghouse on Rural Education and Small Schools.

Kroksmark, T. (1987). Fenomenografisk didaktik. Doktorsavhandling, Göteborg: (Göteborg studies in Educational Sciences; 63) (Acta Universitatis Gothoburgensis).

Kroksmark, T. (2007). Fenomenografisk didaktik: en didaktisk möjlighet. Didaktisk Tidskrift 17(23), 9-15.

Kvale, S. (1997). Den kvalitativa forskningsintervjun. Lund: Studentlitteratur.

Larsson, S. (1986). Kvalitativ analys: exemplet fenomenografi. Lund: Studentlitteratur.

Larsson, S. (2005). Om kvalitet i kvalitativa studier. I: Nordisk Pedagogik, 25(1), 16-35.

Larsson, S. (2009). A pluralistis view of generalization in qualitative research. I: International Journal of Research \& Method in Education, 32(1), 25-38.

Lennon, J., Jonston, D., Marshall, D., McConvell, P., Nicholls, W., Pearson, M \& Sullivan, S. (2001). Natural and Cultural Heritage (Theme Report). Australian Government. Canberra: Publ. CSORO AU. Hämtad 30 december 2011, från www.environment.gov.au/soe/2001/publications/themereports/heritage/glossary.html

Løvlie, L. (2007). The Pedagogy of Place. Nordisk Pedagogik, 27(1), 32-37.

Lundgren, L. J. (2006). Sumpmarken som blev ett vattenrike. I: E. Morald \& C. Nordlund (Red.), Topos: Essäer om tänkvärda platser och platsbundna tankar. Stockholm: Carlsson Bokförlag.

Lundegård, I., Wickman, P.-O., \& Wohlin, A. (Red.), (2004). Utomhusdidaktik. Lund: Studentlitteratur.

Magntorn, O. (2007). Reading Nature: Developing ecological literacy through teaching. Doctoral dissertation, Linköping University. Linköping: Studies in Science and Technology Education No 6.

Marton, F., \& Booth, S. (2000). Om lärande. Lund: Studentlitteratur.

Moser, T., \& Dudas, B. (2007). Lek bevegelse og avspenning: En pilotstudie av hvilke konsekvenser innføringen av spesifikke møbler og romorganisering fär for barns aktiviteter $i$ barnehagen. Prosjektrapport. Vestfold: Høgskolen i Vestfold.

Moser, T. (2007). Rommet som pedagogisk (kon) tekst og det fysiske miljøet som læremiddel. I: S. V. Knudsen, S. Dagrun, \& B. Aamotsbakken (Red.), Tekst i vekst: Teoretiske, historiske og analytiske perspektiver på pedagogiske tekster. Oslo: Novus Forlag.

Mygind, E., \& Herholdt, L. (2005). Sammenfatning af naturklasseprojektet. I: E. Mygind (Red.), Udeundervisning i folkeskolen (s.36-62). København: Museum Tusculanums forlag.

Lundgren, L. J., (2006). Sumpmarken som blev ett vattenrike. I: Mårald, E. \& Nordlund, C. (Red.), Topos: Essäer om tänkvärda platser och platsbundna tankar (s.254). Stockholm: Carlsson Bokförlag.

Mårtensson, F. (2004). Landskapet i leken: En studie av utomhusleken på förskolegården. Doktorsavhandling, Agraria 464 Alnarp: Sveriges lantbruksuniversitet (SLU). 
NE. (2012). Nationalencyklopedin nätversion. Sökord: Plats. Hämtad 10 mars 2012, från www.ne.se. lt.ltag.bibl.liu.se/topos

NE. (2012). Nationalencyklopedin nätversion. Sökord: Ställe. Hämtad 10 mars 2012, från www. ne.se.lt.ltag.bibl.liu.se/sve/ställe?i_h_word=ställe

Neisser, U. (1994). Self-perception and self-knowledge. Danish journal Psyke \& Logos, 15, 392-407.

Sandberg, M. (2009). Barn och natur i storstaden: En studie av barns förhållande till naturområden i hemmets närhet - med exempel från Stockholm och Göteborg. Licentiatavhandling, CHOROS

(1) Göteborg: Institutionen för kulturgeografi och ekonomisk geografi, Göteborgs universitet.

Sharp, L. B. (1943).”Outside the Classroom”, The Educational Forum, May, 7(4). Hempstead, New York: USA.

Skyum - Nielsen, P. (Red.), (1995). Text and quality: studies of educational texts. Oslo: Scandinavian University Press.

Smith, G. (2002). Place-based education: Learning to be where we are. Phi Delta Kappan, 83(8), 584-594.

Sobel, D. (2004). Place-Based Education: Connecting Classrooms \& Communities, Great Barrington, MA: The Orion Society.

Szczepanski, A. (2008). Handlingsburen kunskap: Lärares uppfattningar om landskapet som lärandemiljö. Licentiatavhandling, Linköping: Linköpings universitet, Institutionen för beteendevetenskap och lärande, Institutionen för kultur och kommunikation, Estetiska avdelningen.

Szczepanski, A. (2011). Utomhusutmaningar. I: Education and Sustainability, Alternativa lärmiljöer, Utomhuspedagogik 5, 32-34 (upplaga Sverige). Malmö: Malmö högskola.

Thomashow, M. (1996). Ecological Identity: Becoming a Reflective Environmentalist. Cambridge: MIT Press.

Trost, J. (2005). Kvalitativa intervjuer. Lund: Studentlitteratur.

Tuan, Y.-F. (1974). Topophilia: a study of environmental perception, attitudes, and values. Prentice Hall, Englewood Cliffs, N.J.

Tuan, Y.-F. (2005). Space and Place: The Perspective of Experience. Minneapolis: University of Minnesota Press.

Uljens, M. (1989). Fenomenografi: forskning om uppfattningar. Lund: Studentlitteratur.

Uljens, M. (1998). Fenomenografin, dess icke-dualistiska ontologi och Menons paradox. I: Pedagogisk forskning i Sverige. 3(2), 122-129.

Vetenskapsrådet, (2006). Forskningsetiska principer inom humanistisk samhällsvetenskaplig forskning. Hämtad 19 maj 2012, från www.codex.vr.se

Vetenskapsrådet, (2011). God forskningssed. Hämtad 8 mars 2012, från www.vr.se/download/18.3a 36c20d133afoc12958000491/God+forskningssed+2011.1.pdf

Westlund, I. (1996). Skolbarn av sin tid: En studie av skolbarns upplevelse av tid. Doktorsavhandling, Linköping: Linköping Studies in Education and Psychology No. 49, Department of Education and Psychology.

Wickenberg, P. (1999). Normstödjande strukturer: Miljötematiken börjar slå rot i skolan. Doktorsavhandling, Lund: Lund Studies in Sociology and Law 5, Department of Sociology, Sociology and Law.

Wilhelmsson, B. (2012). Teachers' intensions for outdoor education: conceptualizing learning in different domains. Licentiatavhandling, Umeå: Umeå universitet, Department of Science and Mathematics Education.

von Wright, M. (2011). Om undran inför mattan: Pedagogisk-filosofiska undersökningar om delaktighet i skolan. I: T. Kvernbekk (Red.), Humaniorastudier I Pedagogik: Pedagogik filosofi og historia (s.171-179). Oslo: Abstrakt forlag AS.

Zini, M., \& Zoboli, C. (2002). Atelier 3 furnishings for young children. Reggio Emilia, Italia: ISAFF. Åkerblom, P. (2005). Lära av trädgård: Pedagogiska, historiska och kommunikativa förutsättningar för skolträdgårdsverksamhet. Doktorsavhandling, Uppsala: Sveriges lantbruksuniversitet (SLU), Alnarp. 